Article

\title{
Optimal Design Strategy of a Solar Reflector Combining Photovoltaic Panels to Improve Electricity Output: A Case Study in Calgary, Canada
}

\author{
Moon Keun Kim ${ }^{1, *}$, Khalid Osman Abdulkadir ${ }^{2}$, Jiying Liu ${ }^{3}\left(\mathbb{D}\right.$, Joon-Ho Choi ${ }^{4}\left(\mathbb{D}\right.$ and Huiqing Wen ${ }^{5}$ \\ 1 Department of Civil Engineering and Energy Technology, Oslo Metropolitan University, 0130 Oslo, Norway \\ 2 Information Technology \& Services, Green Bee Energy, Dubai 296360, United Arab Emirates; \\ khalid@greenbenergy.com \\ 3 School of Thermal Engineering, Shandong Jianzhu University, Jinan 250101, China; jxl83@sdjzu.edu.cn \\ 4 School of Architecture, University of Southern California, Los Angeles, CA 90089, USA; Joonhoch@usc.edu \\ 5 Department of Electrical and Electronic Engineering, Xi'an Jiaotong_Liverpool University, Suzhou 215123, \\ China; huiqing.wen@xjtlu.edu.cn \\ * Correspondence: Moon.Kim@oslomet.no or yan1492@gmail.com; Tel.: +47-67-23-65-57
}

check for

updates

Citation: Kim, M.K.; Abdulkadir, K.O.; Liu, J.; Choi, J.-H.; Wen, H. Optimal Design Strategy of a Solar Reflector Combining Photovoltaic Panels to Improve Electricity Output: A Case Study in Calgary, Canada. Sustainability 2021, 13, 6115. https:// doi.org/10.3390/su13116115

Academic Editors: Gerardo Maria Mauro and Tomonobu Senjyu

Received: 24 March 2021

Accepted: 21 May 2021

Published: 28 May 2021

Publisher's Note: MDPI stays neutral with regard to jurisdictional claims in published maps and institutional affiliations.

Copyright: (c) 2021 by the authors. Licensee MDPI, Basel, Switzerland. This article is an open access article distributed under the terms and conditions of the Creative Commons Attribution (CC BY) license (https:/ / creativecommons.org/licenses/by/ $4.0 /)$.

\begin{abstract}
This study explores the combination of photovoltaic (PV) panels with a reflector mounted on a building to improve electricity generation. Globally, PV panels have been widely used as a renewable energy technology. In order to obtain more solar irradiance and improve electricity output, this study presents an advanced strategy of a reflector combining PV panels mounted on a building in Calgary, Canada. Based on an experimental database of solar irradiances, the simulation presents an optimal shape designed and tilt angles of the reflector and consequently improves solar radiation gain and electricity outputs. Polished aluminum is selected as the reflector material, and the shape and angle are designed to minimize the interruption of direct solar radiation. The numerical approach demonstrates the improvement in performance using a PV panel tilted at $30^{\circ}, 45^{\circ}, 60^{\circ}$, and $75^{\circ}$ and a reflector, tilted at $15.5^{\circ}$ or allowed to be tilted flexibly. A reflector tilted at $15.5^{\circ}$ can improve solar radiation gains, of the panel, by nearly $5.5-9.2 \%$ at lower tilt angles and $14.1-21.1 \%$ at higher tilt angles. Furthermore, the flexibly adjusted reflector can improve solar radiation gains on the PV panel, by nearly $12-15.6 \%$ at lower tilt angles and $20-26.5 \%$ at higher tilt angles. A reflector tilted at $15.5^{\circ}$ improves the panel's output electricity on average by $4-8 \%$ with the PV panel tilted at $30^{\circ}$ and $45^{\circ}$ respectively and $12-19 \%$ with the PV panel tilted at $60^{\circ}$ and $75^{\circ}$, annually. Moreover, a reflector that can be flexibly tilted improves electricity output on average by $9-12 \%$ with the PV panel tilted at $30^{\circ}$ and $45^{\circ}$ and $17-23 \%$ with the PV panel tilted at $60^{\circ}$ and $75^{\circ}$. Therefore, the utilization of a reflector improves the performance of the PV panel while incurring a relatively low cost.
\end{abstract}

Keywords: photovoltaic panel; reflector; electricity generation; solar radiation; tilt angle

\section{Introduction and Background}

With our developing industries and growing world population, building energy consumption has increased to maintain peoples' standard of living. Fossil fuel sources have been much more challenging to use in our community because they are the main resources of greenhouse gas and global warming [1,2]. Therefore, renewable energy should be utilized in a clean and sustainable manner. In the last 30 years, solar energy has been increasingly utilized as the main renewable source of energy, and the power output technology is efficiently developed by reducing the cost of production [1-3]. Compared with other renewable sources, solar energy is also easily accessible, and it can be simply connected and merged to the buildings and not necessarily in remote places $[2,4,5]$.

Many studies present optimal design methods of tilt angle studies to generate more electricity output of solar panels in many local areas because the tilt angle and orientation of photovoltaic (PV) panel proportionally impact the electricity output [6-15]. In order 
to improve the performance of PV panel systems, studies showed different optimal tilt angle design strategies. Some studies used the tilt angle design method based on earth-sun geometry $[10,16,17]$. Some of the studies showed linear expressions using latitude and optimal tilt angle [18]. Breyer and Schumid [19] utilized methods combining satellite data with geometric and radiative equations. Ekpenyoung et al. [20] presented a polynomial model for adapting to the winter season. Jacobson and Jadhav [8] used PVWatt to combine solar irradiance data with 30 years' historical climate data from a meteorological station.

Literature showed that the tracking panel system is much more efficient than a fixed panel system [21,22]. Moreover, Helwa et al. [23] and Hassan [24] described that the double-axis tracking system has more power than a single-axis tracking system. However, a solar tracking system has limitations to be used on the rooftop of a building because it is expensive and has high maintenance cost [25-29]. It is limited by harsh weather conditions such as snowy and windy environments $[27,30,31]$. Significant energy is consumed when it is used [32,33].

Some studies show the possibility of improving the power generation of PV panels using a reflector [34,35]. Huang and Sun [34] illustrated that a compact fixed $2 x$ reflector can generate solar power by $23 \%$ for PV systems with a tilt angle, $25^{\circ}$. Kostic et al. [35] presented that an aluminum sheet reflector obtained $17.1 \%$ of total thermal energy. Pavlovic and Kostic [36] simulated the performance of the top and bottom reflectors, and the effect of the bottom reflectors was two times higher than from the top one.

Each material has its specific albedo value or reflective radiation index [37]. The value 1 is for fully reflective materials, and the value 0 is for fully absorbing materials. For example, a black pavement material and snow-covered ground represent an albedo value of $\sim 0.1$ and 0.6 , respectively [38,39]. A reflect material with a high specular albedo level can increase solar radiation gains on PV panels. But we should consider other characteristics such as fragility, thermal conductivity, or cost value for practicality. Kostic et al. [12,35] and Pavlovic et al. [36] showed that the reflector could increase the total electrical energy around $8-12 \%$ and total thermal energy around $22-39 \%$ during the summer season. Therefore, the combination of photovoltaic (PV) panels with a reflector can reduce the payback time.

This study identifies the reflective materials that are practical candidates for mounting on buildings based on a specific set of criteria. The main objective is to strategically place the optimized reflector using a particular shape on to the PV panels to obtain higher irradiance, increasing the power output efficiency and minimizing the solar shading effect by the reflector. We designed a solar reflector based on the solar path diagram in case an optimized solar reflector can block direct solar irradiation to the PV panels. This designed reflector can flexibly adjust tilt angles of the reflect panel, and it maximizes electricity outputs by PV panels adapting seasonal changes and solar altitude change. The increased power output is then compared to that of the conventional PV panels without a reflector. Poulek et al. [40] described that the higher operating temperature of PV cells reduced the annual electricity production by $3-4 \%$ in cold and moderate climates and by more than $5 \%$ in hot climates. Especially the Himalayas and Southern Andes regions have very strong solar energy potential due to a large amount of solar irradiation and relatively lower temperatures [41]. Due to the low irradiance experienced by countries located far from the equator, this study focuses on the buildings, specifically in Calgary, Canada, a low-temperature region. If there is the same amount of solar irradiation in countries, the colder countries with a low ambient temperature gain an advantage to reduce the PV panels' surface temperature [42].

The analysis includes the following:

- Analyzing collected global and direct solar irradiance levels and calculating the solar radiation levels based on PV tilt angles;

- Designing an optimal reflector size and tilt angle to minimize solar shading effect and to maximize the solar electricity outputs;

- Analyzing the reflector's performance based on local condition, e.g., Calgary, Canada; 
- Determining the impact of a solar reflector and optimizing the tilt angles to maximize the performance of the PV panels.

\section{Methods}

For this study, conventional PV panels were first designed to simulate, and the analysis implemented was based on the geographical location, size, and position of the PV system [41,42]. A crucial factor to be considered is the seasonal changes as the sun's positions in the sky vary depending on the time of the year. Further, it is essential to identify the power consumption to standardize the analysis. For this purpose, the consumption of an average Calgary residential house was considered, which installs PV panels on the roof. The reflective material selection was based on a weighted set of criteria. The highest weightage was undoubtedly given to the reflectivity of the material; however, consideration was also given to the applied nature of the reflectors and other weighted criteria. Thus, the final choice was based on a cumulative value of these set conditions. The positioning of the reflector was based on the sun's daily motion (east to west), and the size of the reflector took into consideration the angle of the incident and reflected rays.

The additional radiation was calculated by utilizing the equation for reflected radiation on a tilted surface, which considers: the tilt angle of the panel, the tilt angle of the mirror, the average daily global radiation, and the albedo level of the reflector. The irradiation value of the panels was used to calculate its power output. Finally, space-saving was also calculated based on the new PV panels that achieved the initially required power output.

\subsection{Site and Simulation Description}

For the setup of the PV panels, the geographical location of Calgary, Canada, were identified as follows:

Latitude: $51.05^{\circ}$

Longitude: $-114.06^{\circ}$

Further, two specific orientations were considered:

Azimuth-Compass angle of the sun as it moves from east to west during the day (True South $=0^{\circ}$ ).

Zenith-The angle the sun subtends with the horizon. This angle varies throughout a calendar year.

Initially considering azimuth and a location of our site in northern hemisphere, the panels would be faced toward south and equator. Further, the zenith data, NASA (National Aeronautics and Space Administration) Meteorology [43] and Natural Resources Canada database [44] were utilized to obtain the Global Horizontal Irradiance (GHI), Direct Normal Irradiance (DNI), and the perpendicular alignment of the sun with the PV panel during the varying solstice. This study used seven years of average GHI and DNI daily data for Calgary, Canada. For sizing of PV panels, parameters were based on an average household with a home size of $185 \mathrm{~m}^{2}$, and four occupants. Figure 1 illustrates the design of a solar reflector. The shape of the reflector is designed based on the solar path diagram at the spring equinox, i.e., $21 \mathrm{March}$, to ensure that the reflector does not block the direct solar irradiance. In order to demonstrate the performance of the designed reflector, this study considers various $\mathrm{PV}$ panel tilt angles, namely, $30^{\circ}, 45^{\circ}, 60^{\circ}$, and $75^{\circ}$ and a reflector tilt angle of $15.5^{\circ}$, which is the solar altitude angle during the winter solstice in Calgary, Canada and a flexibly changing tilt angle based on the sun's seasonal declination differences at the site. The angle of the lowest meridian transit altitude at Calgary for a whole year is $15.5^{\circ}$. For example, if a reflector tilt angle is higher than $15.5^{\circ}$ in December, the reflector can shade the direct solar irradiance toward the PV panels. The reflector with a tilt angle, $15.5^{\circ}$ cannot interrupt the direct solar irradiance toward the PV panel. Hence, the reflector tilt angle of $15.5^{\circ}$ is a maximum fixed angle allowed for Calgary region. The reflector design is presented in Figures 1 and 2. The reflector angle must be lower than the meridian transit altitude; otherwise, the reflector can block the direct solar irradiance directed toward the 
PV panels. This study shows two tilt reflector angles, $15.5^{\circ}$ fixed and flexibly changing, considering the monthly meridian transit altitude.
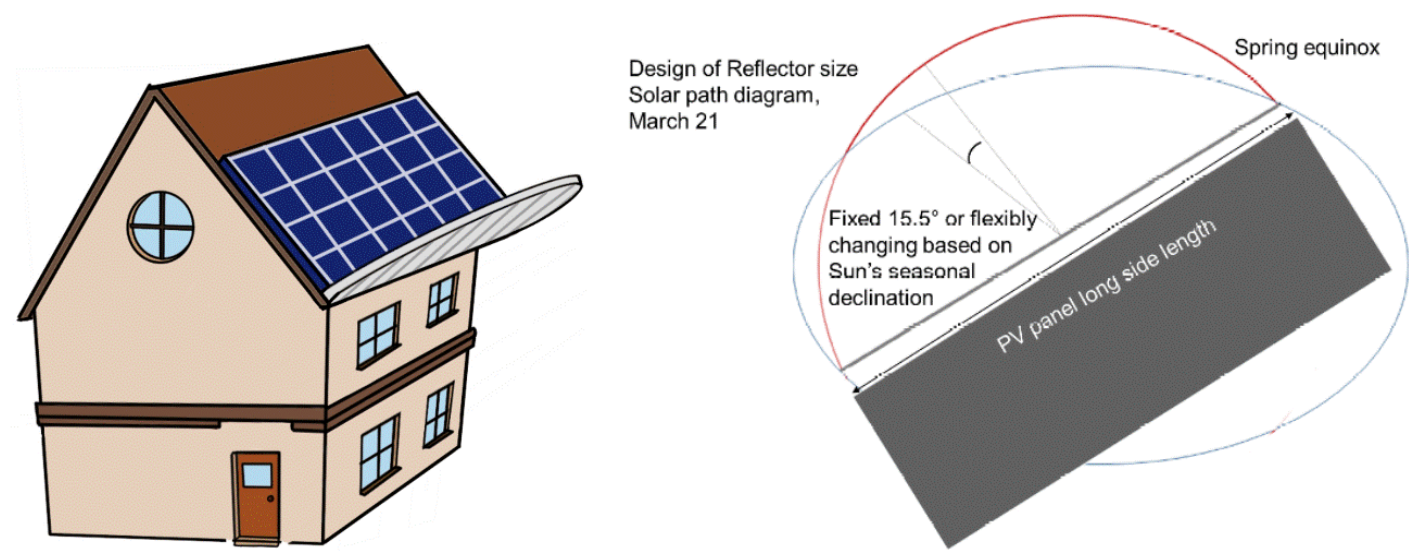

Figure 1. Design of reflector shape and size.

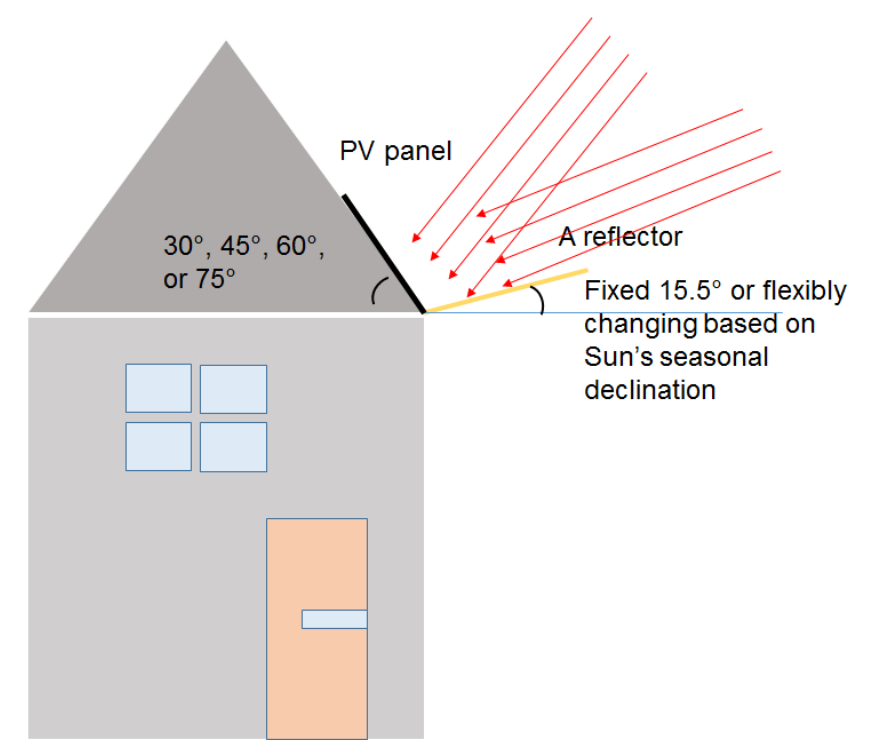

Figure 2. Schematic of PV panel array with a reflector.

Longi PV Panels were selected for this research, with the following specifications:

Power $=350 \mathrm{~W}$

Impp $=9.16 \mathrm{~A}$

$\mathrm{Vmpp}=38.2 \mathrm{~V}$

Efficiency $=16.5 \%$

Area $=1.9 \mathrm{~m}^{2}$

Irradiance level and average temperature for all the months were considered [43].

The ideal energy generation by the PV system is calculated in the following formula. The $P_{p v}$ array watt peak is further calculated using the equation below [45]. The electricity for the customer considers the radiation at the optimum angle, temperature correction factor, cable, conversion, and mismatching losses.

$$
P_{p v}\left(W_{p}\right)=\frac{\text { Daily Power Consumption }}{Z_{1} \times Z_{2} \times V_{T}}
$$


where, $P_{p v}=$ PV array, Watt Peak, $Z_{1}=$ radiation at optimum angle, $Z_{2}=$ temperature correction factor, $V_{T}=\mathrm{V}_{\mathrm{L}} \times \mathrm{V}_{\mathrm{A}} \times \mathrm{V}_{\mathrm{u}}, V_{T}=$ overall loss, $\mathrm{V}_{\mathrm{L}}=$ cable losses, $\mathrm{V}_{\mathrm{A}}=$ mismatching losses (e.g., Lack of MPPT), = conversion losses (e.g., From Battery).

The output power of the total electricity generator at the maximum power point (MPP) is achieved from Equations (2) and (3), where the elements are obtained from the actual manufacture's test data (nominal operating cell temperature (NOCT)) and standard test condition (STC). Literature sources [46-48] have been referenced to calculate the PV panel outputs. The equations follow below:

$$
P_{p v}=\left[P_{p v, S T C} \times \frac{G_{T}}{1000} \times\left[1-\gamma \times\left(T_{j}-25\right)\right]\right] \times N_{P V s} \times N_{P V p}
$$

where, $P_{P V}=$ output power at the MPP, $P_{P V, S T C}=$ the rated PV power at MPP and standard test condition (STC), assuming $165 \mathrm{~W}, G_{T}=$ the irradiance level at STC, $\mathrm{W} / \mathrm{m}^{2}, \Gamma=$ the power temperature coefficient at MPP, $0.043 \% /{ }^{\circ} \mathrm{C}, \mathrm{T}_{j}=$ the cell temperature, $N_{P V s}=$ number of modules in series, $N_{P V p}=$ number of modules in parallel.

The cell temperature is determined by the equation below:

$$
\left.T_{j}=T_{a m b}+\frac{G_{T}}{800} \times(N O C T-20)\right]
$$

$T_{j}=$ the cell temperature, $T_{a m b}=$ the ambient air temperature, $N O C T=$ nominal operating, cell temperature, assuming $45.5^{\circ} \mathrm{C}$.

Energy rating at maximum ambient temperature (EMAT) model presents the total daily solar radiation, $\mathrm{H}\left(\mathrm{Wh} / \mathrm{m}^{2} /\right.$ day), and the maximum ambient temperature, Tmax $\left({ }^{\circ} \mathrm{C}\right)$ is determined using the following regression equation.

$$
\mathrm{E}=\alpha_{1} \mathrm{H}+\alpha_{2} \mathrm{HT}^{-2}{ }_{\max }+\alpha_{3} \mathrm{~T}_{\max }
$$

where $E$ is the total daily electrical energy produced by the module (W/day), and $\alpha_{j}, j=1-3$ are the regression coefficients.

Reflective material selection [49] was based on a set of criteria shown in Table 1. Three reflective materials were ultimately chosen as candidates for comparing "glass mirror," "polished aluminum," and "reflector-coated polytetrafluoroethylene (PTFE)." Table 1 shows the performance of these three reflective materials. Glass mirror demonstrated a very high specular albedo level, and further analysis showed a favorable density and weight. However, the material is extremely fragile and has low thermal conductivity. Therefore, it has low practicality. Further, polished aluminum (Table 1) demonstrated a reasonably high albedo level and slightly higher density. However, the material also showed fragility, high corrosion resistance, and extremely high thermal conductivity. The third candidate, the reflector-coated PTFE (Table 1), demonstrated superiority compared to the other materials; however, it lacked thermal conductivity, an essential factor for energy capture. PTFE materials are vulnerable and changeable by the gained thermal heat. On comparing the three materials, polished aluminum provided the best overall result, making it the most suitable candidate for integrating reflectors with building-mounted PV panels.

Table 1. Reflective material characteristic.

\begin{tabular}{cccc}
\hline Criteria & Glass Mirror & Polished Aluminum & Coated PTFE \\
\hline Albedo & $0.72-0.85$ (Specular) & $0.65-0.75$ (Specular) & 0.8 (Specular) \\
\hline Density (Weight) & $2.5 \mathrm{~g} / \mathrm{cm}^{3}$ & $3.98 \mathrm{~g} / \mathrm{cm}^{3}$ & $2.17 \mathrm{~g} / \mathrm{cm}^{3}$ \\
\hline Fragility & High & Low & Low \\
\hline Corrosion Resistance & High & High & High \\
\hline Thermal Conductivity & $1.7 \mathrm{~W} / \mathrm{m} \cdot \mathrm{K}$ & $39 \mathrm{~W} / \mathrm{m} \cdot \mathrm{K}$ & $0.2 \mathrm{~W} / \mathrm{m} \cdot \mathrm{K}$ \\
\hline
\end{tabular}




\subsection{Analysis of Optimum Tilted Angle of PV and Reflector}

Optimum tilt angle for the PV panel

Several studies $[7,9,10,50-54]$ describe numerical methods to obtain the optimum tilt angle for the PV panel considering the geographical location. The total radiation is primarily composed of three elements, direct solar radiation, diffused solar radiation, and reflected radiation, and is determined by the following relation as $[7,8,50,52,55]$

$$
\mathrm{H}_{\mathrm{T}}=\mathrm{H}_{\mathrm{B}}+\mathrm{H}_{\mathrm{Dt}}+\mathrm{H}_{\mathrm{R}}
$$

where $\mathrm{H}_{\mathrm{T}}, \mathrm{H}_{\mathrm{B}}, \mathrm{H}_{\mathrm{D}}$, and $\mathrm{H}_{\mathrm{R}}$ are the total, direct beam, diffused and reflected solar radiation, respectively, on the tilted angle surface, measured in $\mathrm{kWh} / \mathrm{m}^{2} /$ day.

The direct beam radiation on a tilted angle surface is calculated using the following equation $[8,51,52,56,57]$.

$$
\begin{gathered}
\mathrm{H}_{\mathrm{B}}=\left(\mathrm{H}_{\mathrm{g}}-\mathrm{H}_{\mathrm{d}}\right) \mathrm{R}_{\mathrm{b}} \\
R_{b}=\frac{\cos (\varnothing-\beta) \cos (\delta) \sin (\omega)+\omega_{\text {rad }} \sin (\varnothing-\beta) \sin (\delta)}{\cos (\varnothing) \cos (\delta) \sin (\omega)+\omega_{\text {rad }} \sin (\varnothing) \sin (\delta)}
\end{gathered}
$$

where, $\mathrm{H}_{\mathrm{g}}$ and $\mathrm{H}_{\mathrm{d}}$ are the global radiation and diffused radiation on the horizontal surface, measured in $\mathrm{kWh} / \mathrm{m}^{2} /$ day, and $R_{b}$ is the ratio of the direct beam on tilted angle surface to that on the horizontal surface, $\beta, \varnothing, \omega$, and $\delta$ are tilt angle, latitude of the location, the hour angle, and declination angle.

The declination angle $(\delta)$

$$
\delta=23.45 \times \sin \left[360\left(\frac{284+\mathrm{n}}{365}\right)\right]
$$

where $\mathrm{n}$ is the number of days starting from the 1st of January till the design date

Hour angle $(\omega)$

$$
\omega=\cos ^{-1}(-\tan (\delta) \tan (\varnothing-\beta))
$$

where $\operatorname{sign}(\delta)=\operatorname{sign}(\varnothing)$

$$
\omega=\cos ^{-1}(-\tan (\delta) \tan (\varnothing))
$$

where $\operatorname{sign}(\delta) \neq \operatorname{sign}(\varnothing), \operatorname{sign}(x)=\frac{\mathrm{x}}{|x|}$

Diffused radiation incident on a tilted surface

Diffused radiation, $\mathrm{H}_{\mathrm{Dt}}$ on a tilted surface, is defined by the diffused radiation on a horizontal surface, $H_{d}$ and the ratio, $R_{d}$ as follows:

$$
\begin{gathered}
\mathrm{H}_{\mathrm{D}}=\mathrm{H}_{\mathrm{d}} \mathrm{R}_{\mathrm{b}} \\
R_{d}=\frac{(1+\cos (\beta))}{2}
\end{gathered}
$$

Reflected radiation from the ground surface

$$
H_{R, \text { ground }}=\operatorname{Hg} \rho \frac{(1+\cos (\beta))}{2}
$$

where $\rho$ is the solar reflectivity of the ground.

Several studies have explored the numerical methods to determine the optimal tilt angle for PV panels, such as two-axis tracking and 3-D model simulations with climate models $[6,8,11,58,59]$. Jacobson and Jadhav [8] list the optimal tilt angle at various international locations using 30 years of historical climate data [60]. In the table, the optimal tilt angle at Calgary was determined to be $45^{\circ}$. This study used four tilt angles of the PV panel, namely, $30^{\circ}, 45^{\circ}, 60^{\circ}$, and $75^{\circ}$ to present the performance of the tilted PV panel. After that, we denote the optimal tilt angle of a reflector panel and the performance as well.

Total solar radiation with a reflector 
Total solar radiation with a reflector with objective functions is given as follows.

$$
\mathrm{H}_{\mathrm{Twr}}=\mathrm{H}_{\mathrm{B}}+\mathrm{H}_{\mathrm{Dt}}+\mathrm{H}_{\mathrm{R}}+\mathrm{H}_{\mathrm{wr}}
$$

where $\mathrm{H}_{\mathrm{Twr}}, \mathrm{H}_{\mathrm{B}}, \mathrm{H}_{\mathrm{Dt}}, \mathrm{H}_{\mathrm{R}}$, and $\mathrm{H}_{\mathrm{wr}}$ are the total, direct beam, diffused, reflected solar radiation on the tilted angle surface and solar radiation from a reflector, respectively measured in $\mathrm{kWh} / \mathrm{m}^{2} /$ day.

Figure 3 illustrates a schematic of a reflector and PV panel. Reflected solar irradiance reached the surface of the PV panel. Hence, the total solar radiation, $\mathrm{H}_{\mathrm{Twr}}$ is calculated by the Formula (15) [61]

$$
\begin{aligned}
H_{\text {Twr }} & =\left(H_{g}-H_{d}\right) R_{b}+H_{d} \frac{(1+\cos (\beta))}{2}+H_{g} \rho \frac{(1-\cos (\beta))}{2} \\
& +H_{g} R_{d, \text { reflector }} \rho_{\text {reflector }} R_{\text {size, } \text { eff }} \frac{(1-\cos (\alpha+\beta))}{2}
\end{aligned}
$$

where $\rho_{\text {reflector }}$ is the solar reflectivity of a reflector

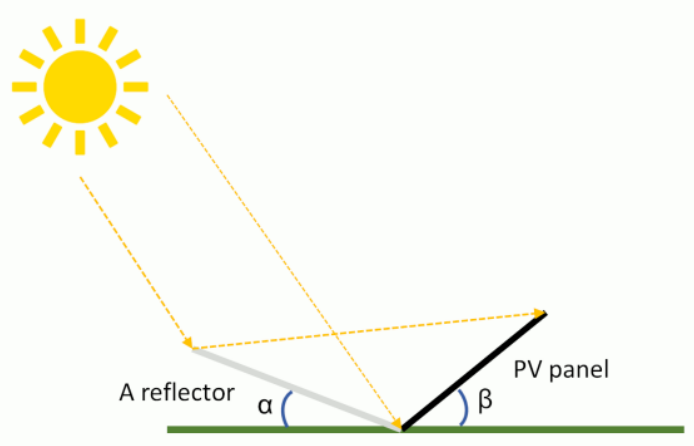

Figure 3. A schematic of a reflector and PV panel.

subject to,

$$
\begin{gathered}
R_{d, \text { reflector }}=\frac{(1+\cos (\alpha))}{2} \\
R_{\text {Size }, \text { eff }}=\frac{\text { Actual reflected area toward PV panel }}{\text { PV panel size }} \text { Rsize.eff } \leq 1
\end{gathered}
$$

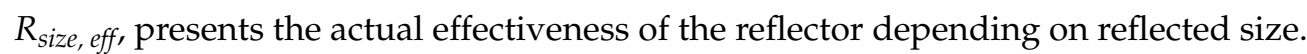
Generally, a larger reflector size leads to an increase in actual PV panel performance; however, the value is limited because the flat plate cannot reflect more solar radiation than the area of the PV panel absorbing the solar radiation. Figure 1 illustrates how to design the solar reflector's size and shape. First, the length of reflector's long side is determined by the same size of the PV panels. The shape follows the solar path diagram of the spring equinox at 21 March. The length of reflector's short side is designed by the same size of PV panels. Hence, the reflector shows a curved shape. Hence, the reflector size is smaller than the PV panels. Based on the reflector size and shape, this study estimated the $R_{\text {size, eff }}$ value to be 0.7 .

\subsubsection{Optimum Reflector Position and Size}

The positioning of the reflectors was based on the Sun's daily motion (east to west), and owing to the static nature of the reflector, the optimal facing position was determined to be southward facing.

Further, for specular reflection, the reflected ray has the same angle as the norm as the incident ray [61]. 
The angle at which the rays hit the reflector can be maximized by increasing the reflector material size. However, for practicality, the size of the reflector is recommended to be the maximum and should not block the solar radiation directed to the PV panel.

\subsubsection{Optimum Reflector Angle}

To analyze the reflected radiation on a tilted surface and to calculate the reflector's optimum angle with respect to the PV panel, the following equation applies [12,52].

$$
\text { Reflector_Factor }=\frac{(1-\cos (\alpha+\beta))}{2}
$$

To improve the performance of the reflector, the Equation (18) determines the optimum angle. This study used four different tilted angles, namely, $30^{\circ}, 45^{\circ}, 60^{\circ}$, and $75^{\circ}$ for the PV panels. Based on the four tilt angles for the PV panels, the optimum reflector tilt angles are determined to maximize the reflector factor value. However, the tilt angle design for the reflector should consider the meridian transit altitude for each month if the designed reflector blocks the solar radiation directed toward the PV panel. For example, the meridian transit altitude at Calgary during the summer and winter solstice is $62.4^{\circ}$ and $15.5^{\circ}$, respectively. Therefore, the actual title angle of the reflector should be lower than $62.4^{\circ}$ and $15.5^{\circ}$ during the summer and winter solstice, respectively. If the reflector tilt angle fixes, for example, on a roof or wall of a building for the whole year, the maximum angle of the reflector is determined to be $15.5^{\circ}$ to avoid the blocking of direct solar radiation to the PV panel. Table 2 illustrated monthly fixed and flexible reflector tilt angles. The flexible reflector tilt angle was designed based on meridian transit altitude for each month.

Table 2. Monthly fixed and flexible reflector tilt angle.

\begin{tabular}{ccc}
\hline Monthly & Fixed Reflector Tilt Angle, ${ }^{\circ}$ & Flexible Reflector Tilt Angle Allowed, $^{\circ}$ \\
\hline January & 15.5 & 19 \\
\hline February & 15.5 & 28 \\
\hline March & 15.5 & 39 \\
\hline April & 15.5 & 50 \\
\hline May & 15.5 & 59 \\
\hline June & 15.5 & 62 \\
\hline July & 15.5 & 59 \\
\hline August & 15.5 & 50 \\
\hline September & 15.5 & 39 \\
\hline October & 15.5 & 28 \\
\hline November & 15.5 & 19 \\
\hline December & 15.5 & 15.5 \\
\hline
\end{tabular}

\section{Results}

\subsection{Sensitivity Analysis of the Impact of a Reflector Tilt Angle}

This study analyzed the optimal tilt angle of the reflector from Equation (15). Figure 4 shows the result of the optimal tilt angles of a reflector for Calgary. The results show that a higher reflector angle significantly impacts the reflection factor with sensitivity analysis. The impact can be maximized using a high tilt angle for the PV panels compared to a lower tilt angle. However, based on the seasonal variation of meridian altitude levels, the tilt angle can be adjusted. For instance, during winter, the actual title angle of the reflector must be adjusted below $15.5^{\circ}$ and below $62.4^{\circ}$ during summer for Calgary, Canada. It is because the reflector panel can block the direct solar radiation toward the PV panels. Therefore, if a reflector's tilt angle can flexibly adjust, the actual reflector factor is maximized to a value 
of $0.53-0.85$. However, if the reflector panel is fixed, the optimal angle is determined to be $15.5^{\circ}$ for Calgary, and the maximum value of the reflection factor is determined to be $0.15-0.5$.

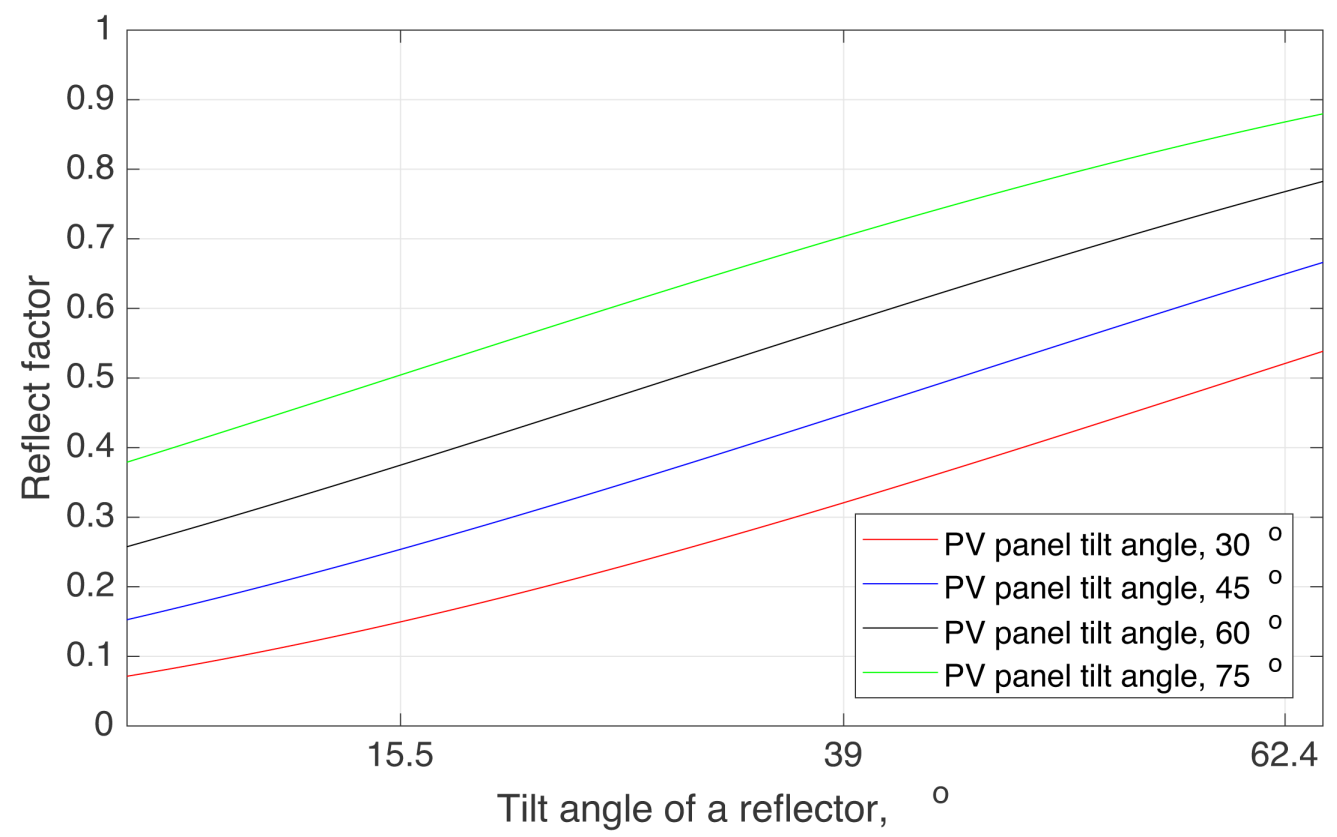

Figure 4. A reflector factor in various tilt angles of a reflector.

\subsection{Numerical Prediction of Solar Radiation with a Sensitivity Analysis}

Figures 5-7 present the solar radiation of $\mathrm{PV}$ panels tilted at $30^{\circ}, 45^{\circ}, 60^{\circ}$, and $75^{\circ}$ with and without the reflector as a numerical prediction with a sensitivity analysis. Figure 5 shows the solar radiation without a reflector. Lower PV panel tilt angles of $30^{\circ}$ and $45^{\circ}$ profoundly affect the solar radiation from April to September; however, higher tilt angles of $60^{\circ}$ and $75^{\circ}$ affect solar radiation from October to March. Figures 6-10 illustrate the reflector's performance tilted at $15.5^{\circ}$ and adjusted flexibly. Overall, the reflector can improve the solar radiation absorption during the shoulder and summer season; however, its effect in the winter is limited. The results illustrate that the reflector strongly impacts the amount of solar radiation on PV panels with higher tilted angles of $60^{\circ}$ and $75^{\circ}$, and the fixed reflector tilted at $15.5^{\circ}$ has lesser influence on the amount of solar radiation on PV panels with lower tilted angles of $30^{\circ}$ and $45^{\circ}$; however, the flexible reflector can improve the amount of solar radiation during the summer season. The fixed reflector tilted at $15.5^{\circ}$ can improve solar radiation on the PV panel by nearly 5.5-9.2\% for PV panels tilted at $30^{\circ}$ and $45^{\circ}$ respectively and $14.1-21.1 \%$ for panel tilted at $60^{\circ}$ and $75^{\circ}$. The flexibly adjusted reflector can significantly improve the solar radiation on the PV panel by nearly $12-15.6 \%$ for panels tilted at $30^{\circ}$ and $45^{\circ}$ respectively and $20-26.5 \%$ for panels tilted at $60^{\circ}$ and $75^{\circ}$. The optimal PV tilt angle $\left(45^{\circ}\right)$ represents intense solar radiation; however, the reflector can compensate for the solar radiation on the PV panel not tilted at the optimal angle. Figure 5 illustrates that during the summer season (June to August), the optimal tilt PV angle is determined to be $30^{\circ}$. However, as shown in Figures 6 and 7, with a reflector, the optimal tilt PV panel angle is $45^{\circ}$ because the reflector helps gather solar radiation for a higher angle tilted panel. Therefore, the optimal tilt PV angle for the summer season can be adjusted to $45^{\circ}$. Figure 10 demonstrates annual solar radiation toward PV panels having four different tilt angles with and without the reflector. The results show how the reflector's tilt angle impacts the extra amount of solar irradiance gained. If a PV panel angle is designed to be higher than $60^{\circ}$ for the location, a reflector can significantly improve the performance to gather solar radiation. 


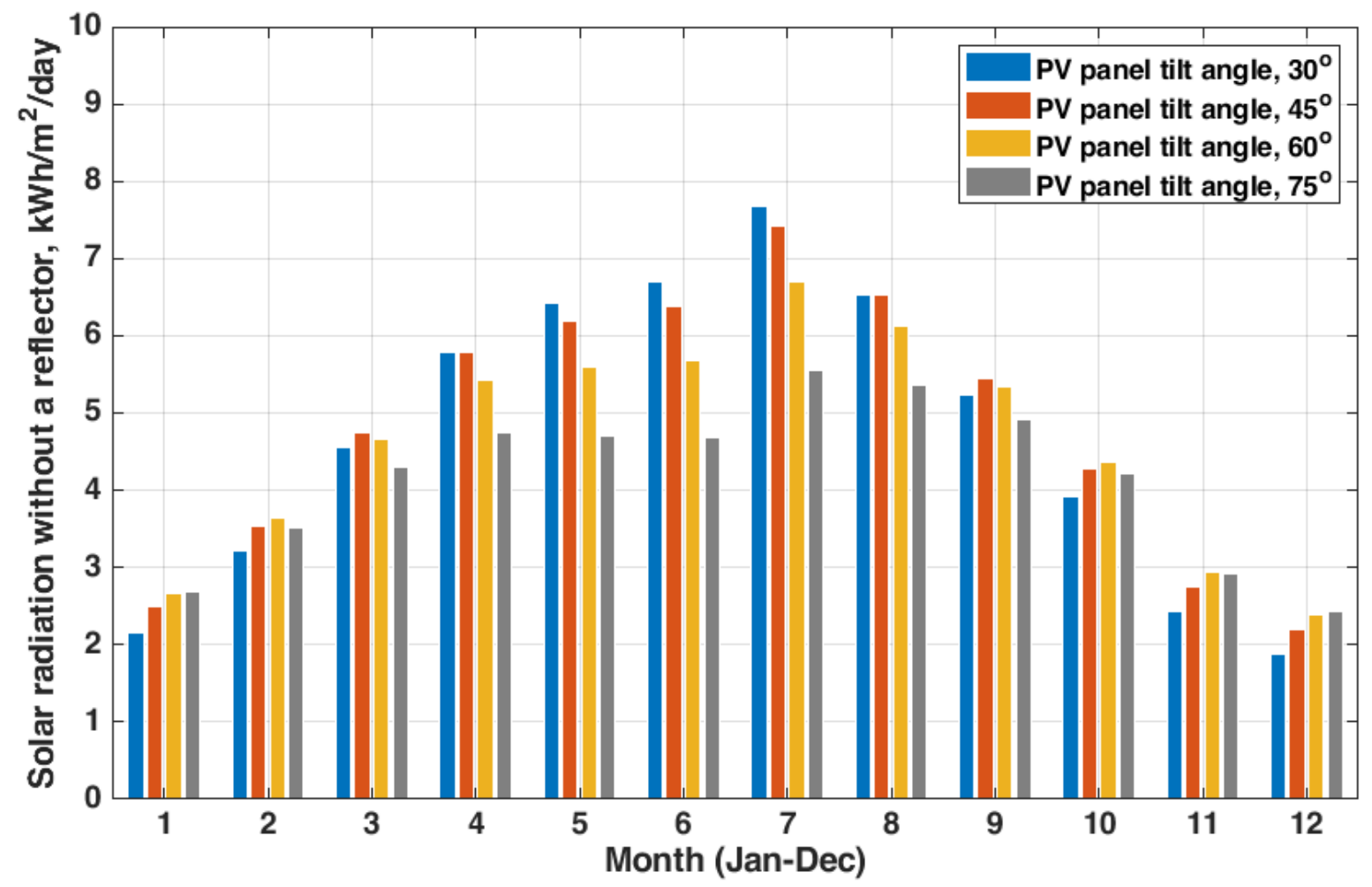

Figure 5. Solar radiation without a reflector.

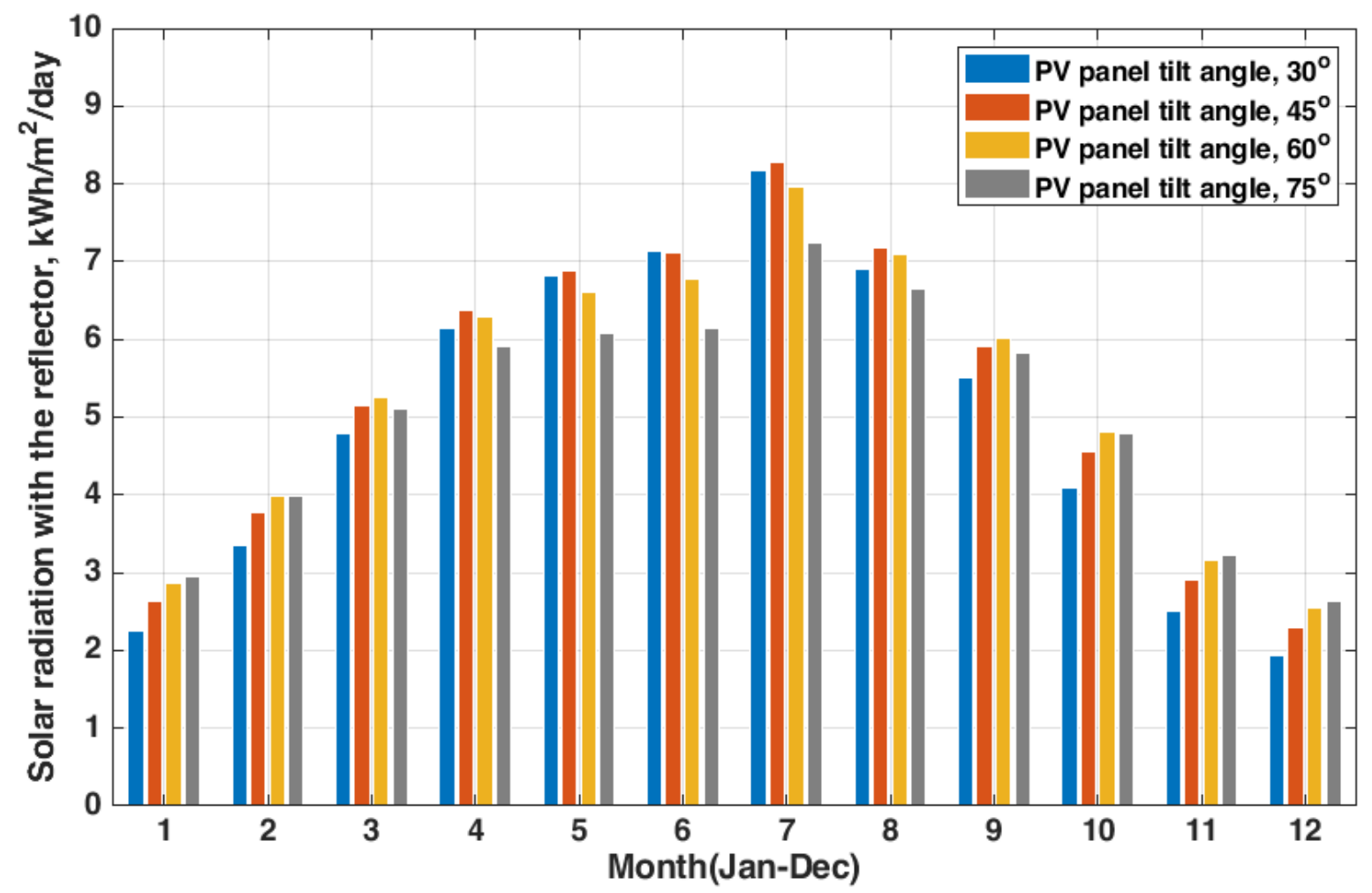

Figure 6. Solar radiation with the reflector tilted $15.5^{\circ}$. 


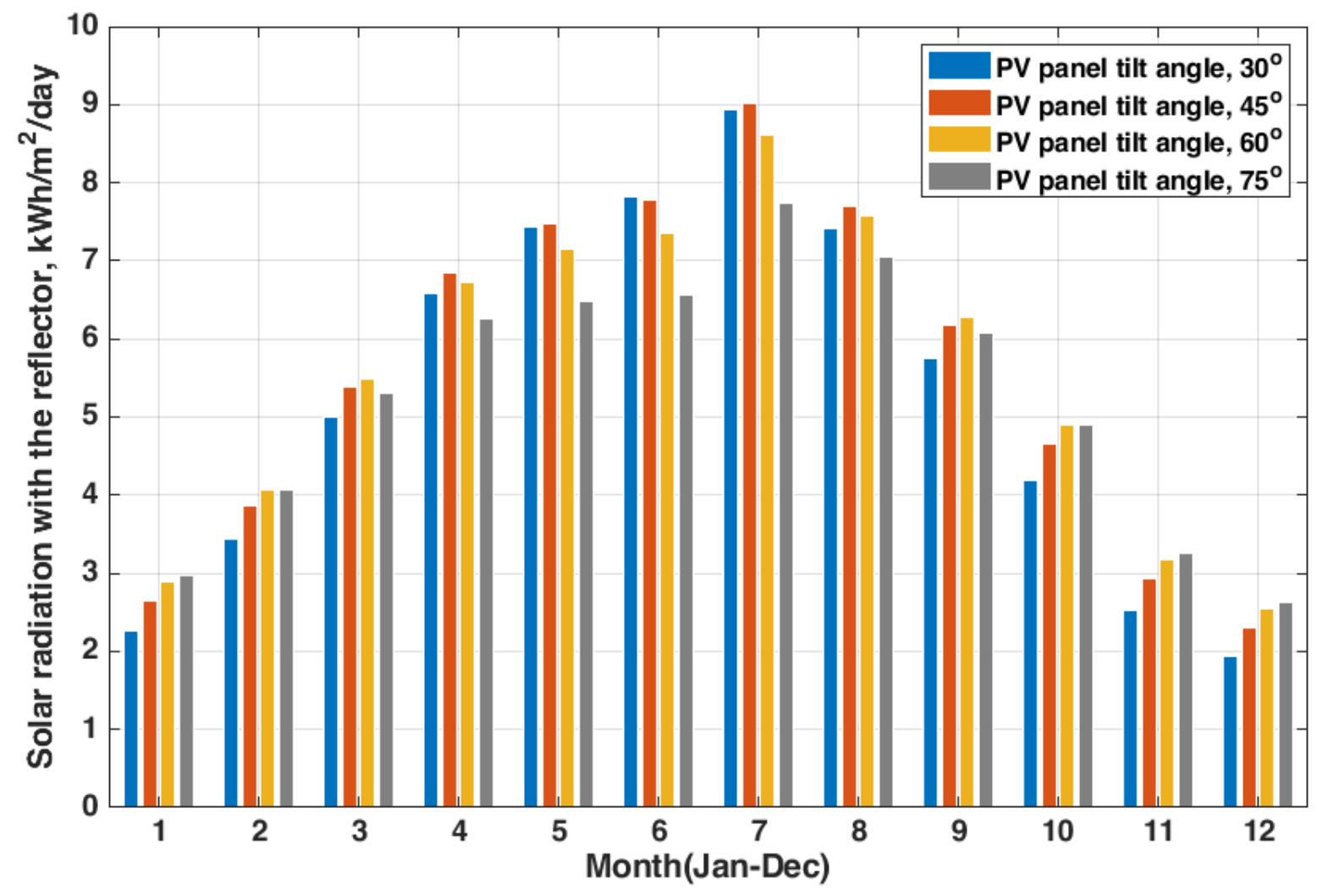

Figure 7. Solar radiation with the reflector tilted flexibly.

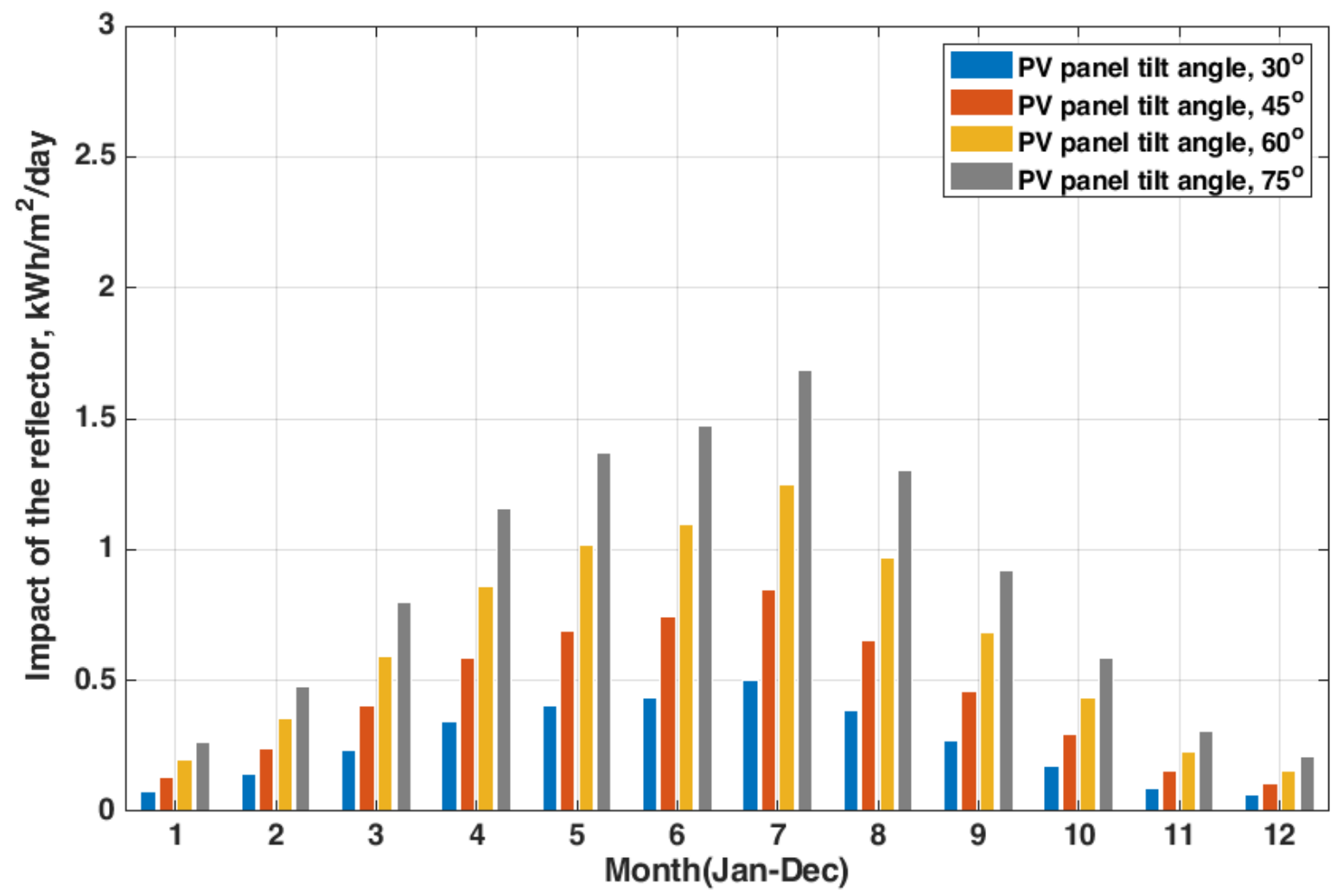

Figure 8. Increased solar radiation with the reflector titled $15^{\circ}$. 


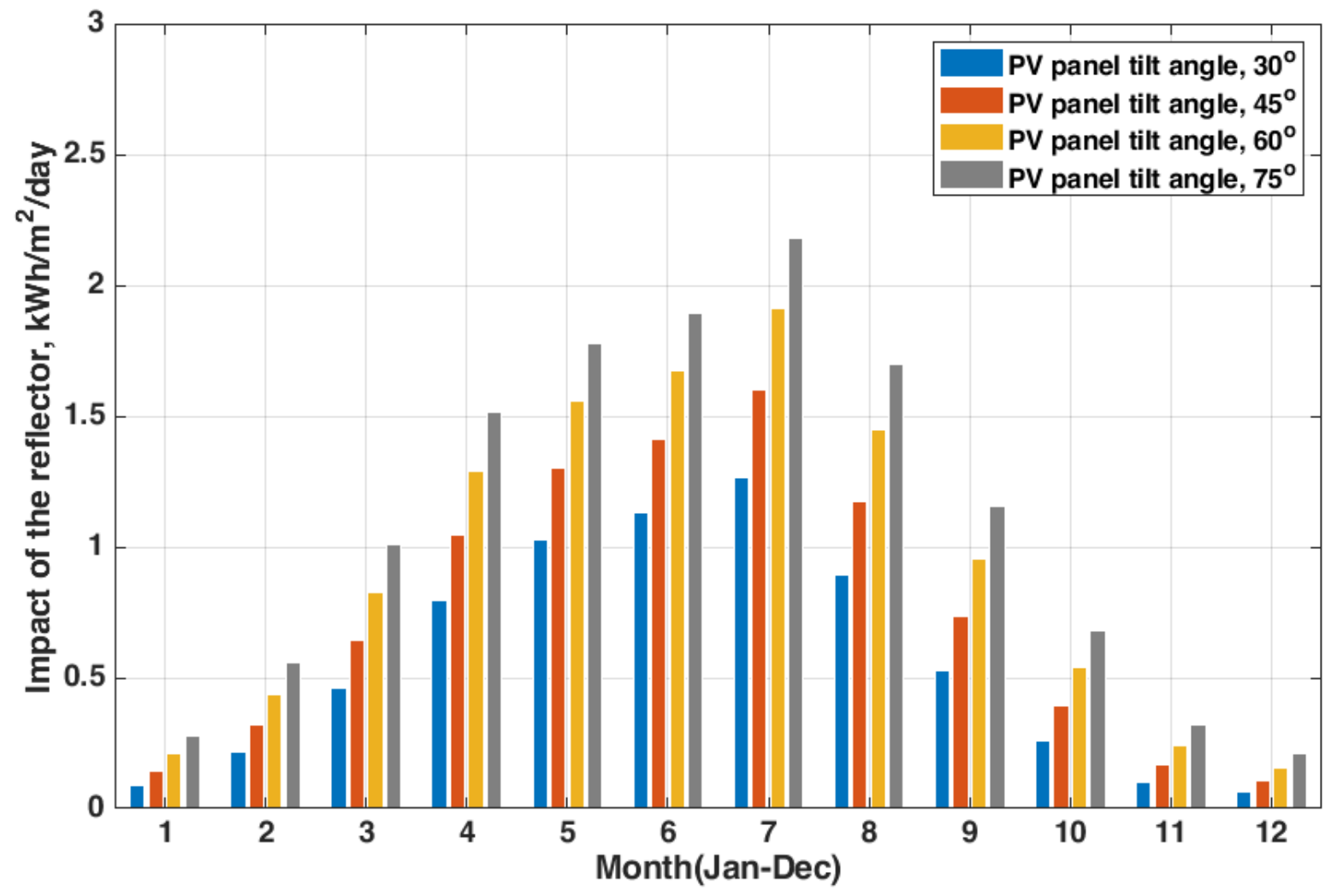

Figure 9. Increased solar radiation with the reflector tilted flexibly.

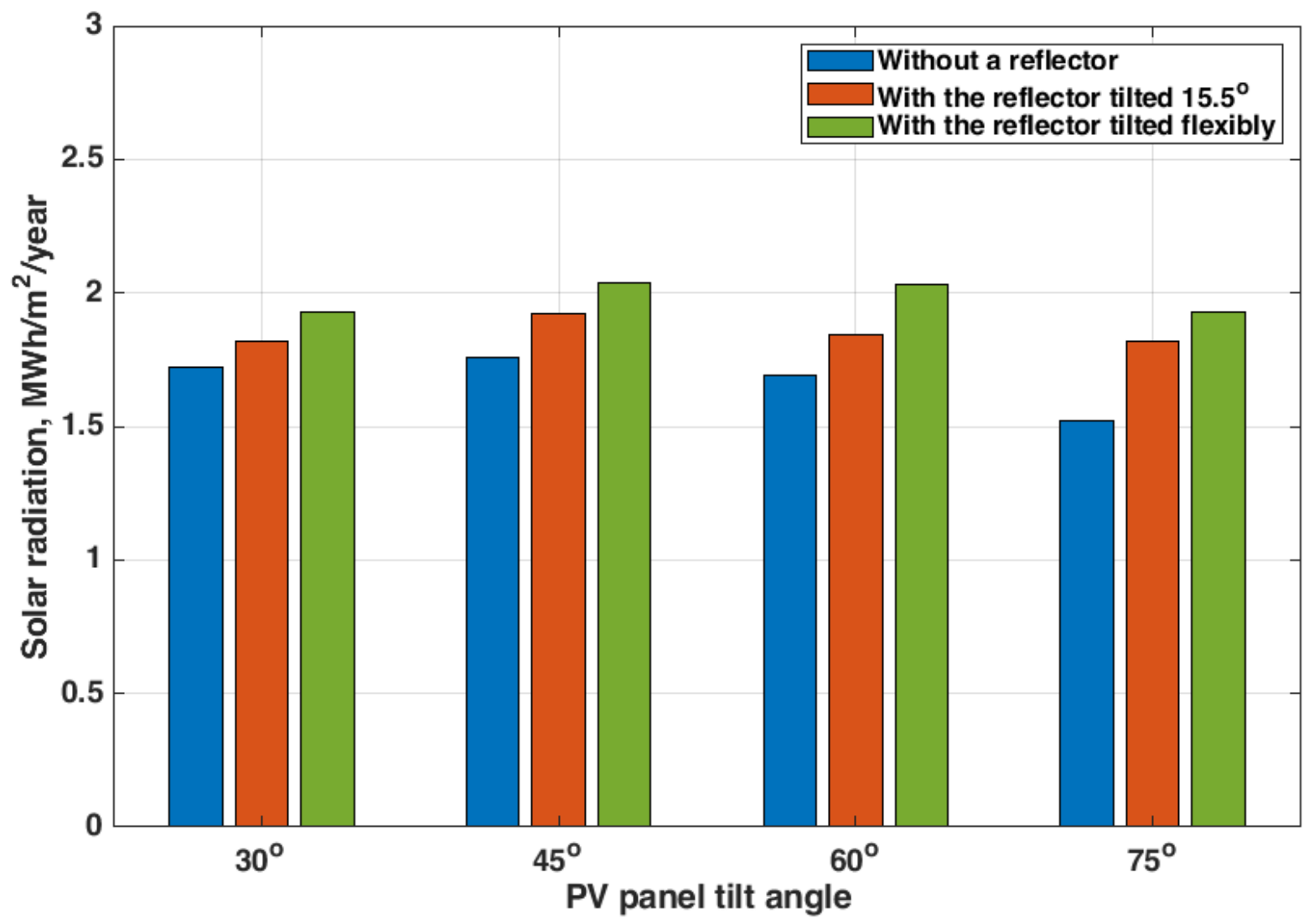

Figure 10. Annual solar radiation toward PV panels having four different tilt angles without and with the reflector. 


\subsection{Analysis of the Predicted Electricity Output of PV Panels with and without a Reflector as a Sensitivity Analysis}

Figures 11-15 illustrate the predicted annual electricity output of PV panels tilted at $30^{\circ}, 45^{\circ}, 60^{\circ}$, and $75^{\circ}$ with and without a reflector as numerical prediction with a sensitivity analysis. The results show that a reflector increases electricity output by $5-15 \%$ for PV panels tilted at $30^{\circ}$ during the summer season and $29-38 \%$ for PV panels tilted at $75^{\circ}$. The reflector tilt angle of $15.5^{\circ}$ has less impact on lower tilted PV panels; however, it significantly impacts the higher tilted PV panel. The reflector tilted at $15.5^{\circ}$ increases electricity output on average by $4-8 \%$ with the PV panel tilted at $30^{\circ}$ and $45^{\circ}$ and $12-19 \%$ with the PV panel tilted at $60^{\circ}$ and $75^{\circ}$ annually. The flexibly tilted reflector can consider seasonal solar meridian transit altitude changes and increases electricity output on average by $9-12 \%$ with PV panels tilted at $30^{\circ}$ and $45^{\circ}$ and $17-23 \%$ with PV panels tilted at $60^{\circ}$ and $75^{\circ}$. Therefore, the utilization of a reflector achieves the same effect of installing a PV panel with the cheaper material cost. Figure 15 illustrates predicted annual electricity outputs having four different tilt angles with and without the reflector. The results present how the reflector's tilt angle impacts the total amount of electricity outputs. If a PV panel angle is designed to be higher than $60^{\circ}$ for the location, a reflector can significantly improve the performance to obtain the electricity outputs. Kostic et al. [12] presented that PV/T(thermal) collectors with an aluminum sheet reflector showed higher energy-saving efficiency. The reflectors also consumed about $10 \%$ of the total cost; however, the additional energy achievement using the reflectors are around $20-35 \%$. An optimal tilt angle of the PV panels obtains higher solar radiation throughout the year. A higher PV panel tilt angle of $60^{\circ}$ and $75^{\circ}$, achieves relatively lower solar radiation; however, a reflector can efficiently compensate for the loss of solar radiation. This analysis demonstrates that a reflector set up with PV panels can obtain a nearly $5-20 \%$ solar radiation gain and consequently increase the electricity output efficiently.

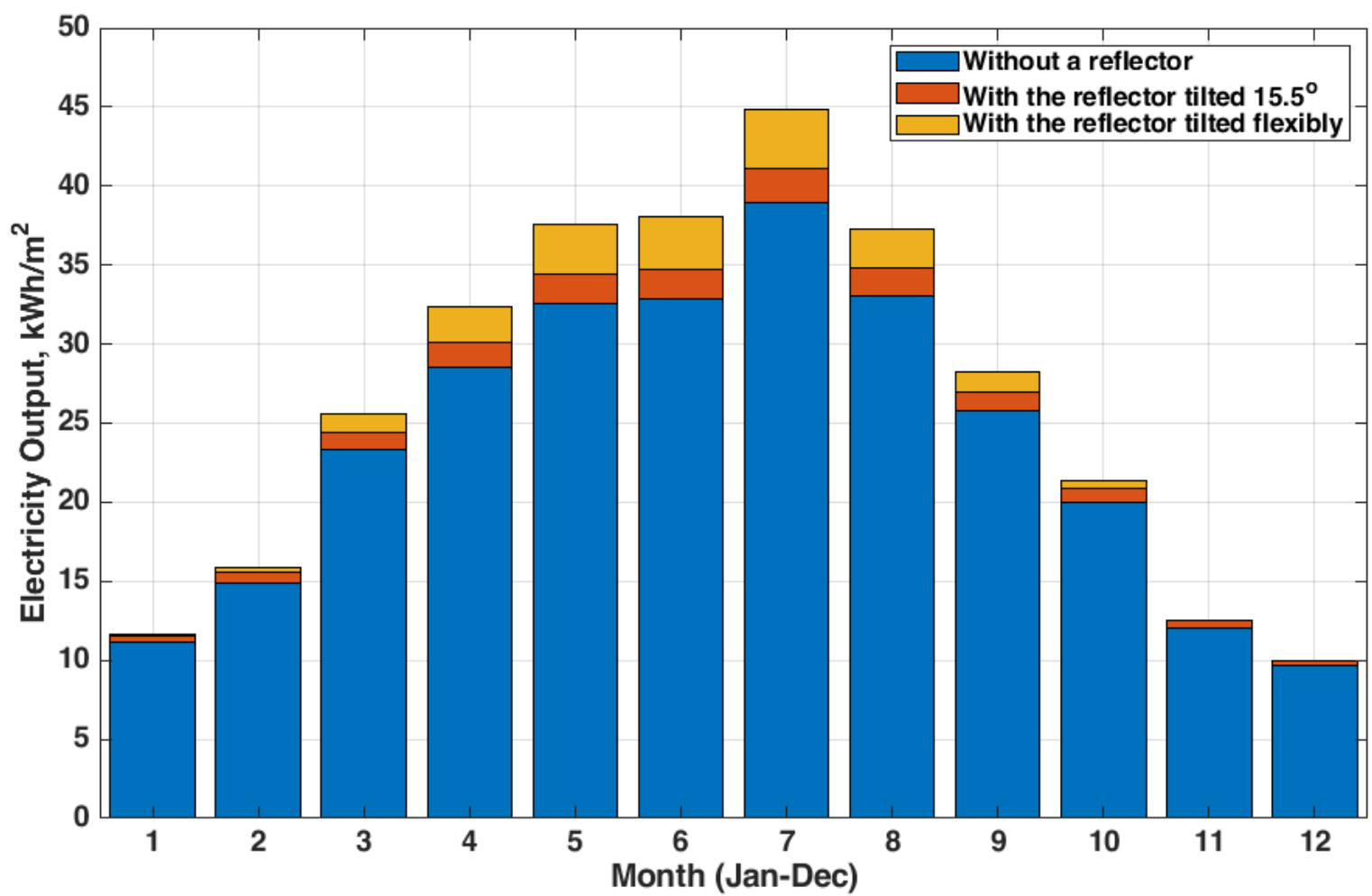

Figure 11. Annual electricity output using PV panels tilted $30^{\circ}$ without and with the reflector. 


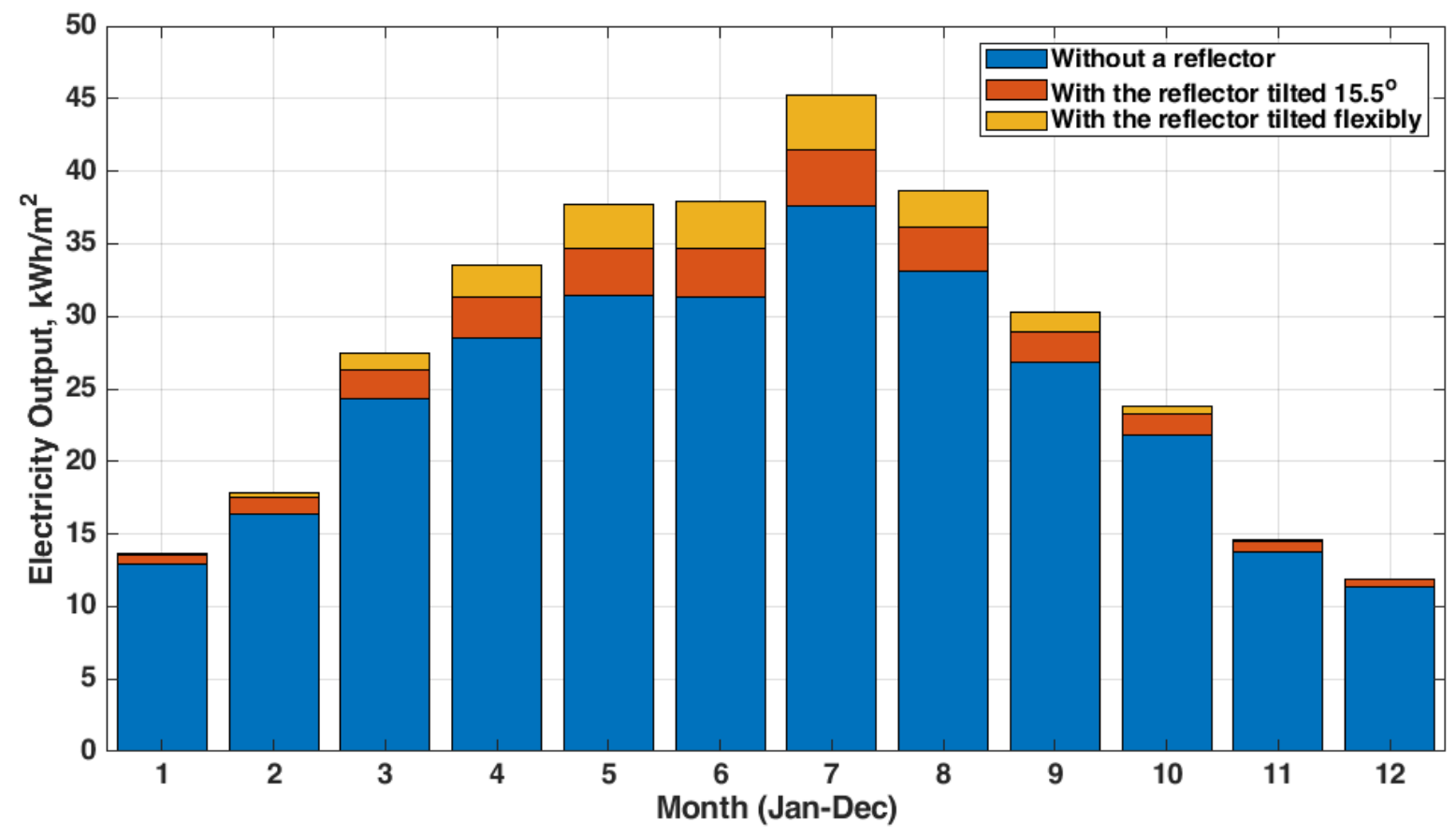

Figure 12. Annual electricity output using PV panels tilted $45^{\circ}$ without and with the reflector.

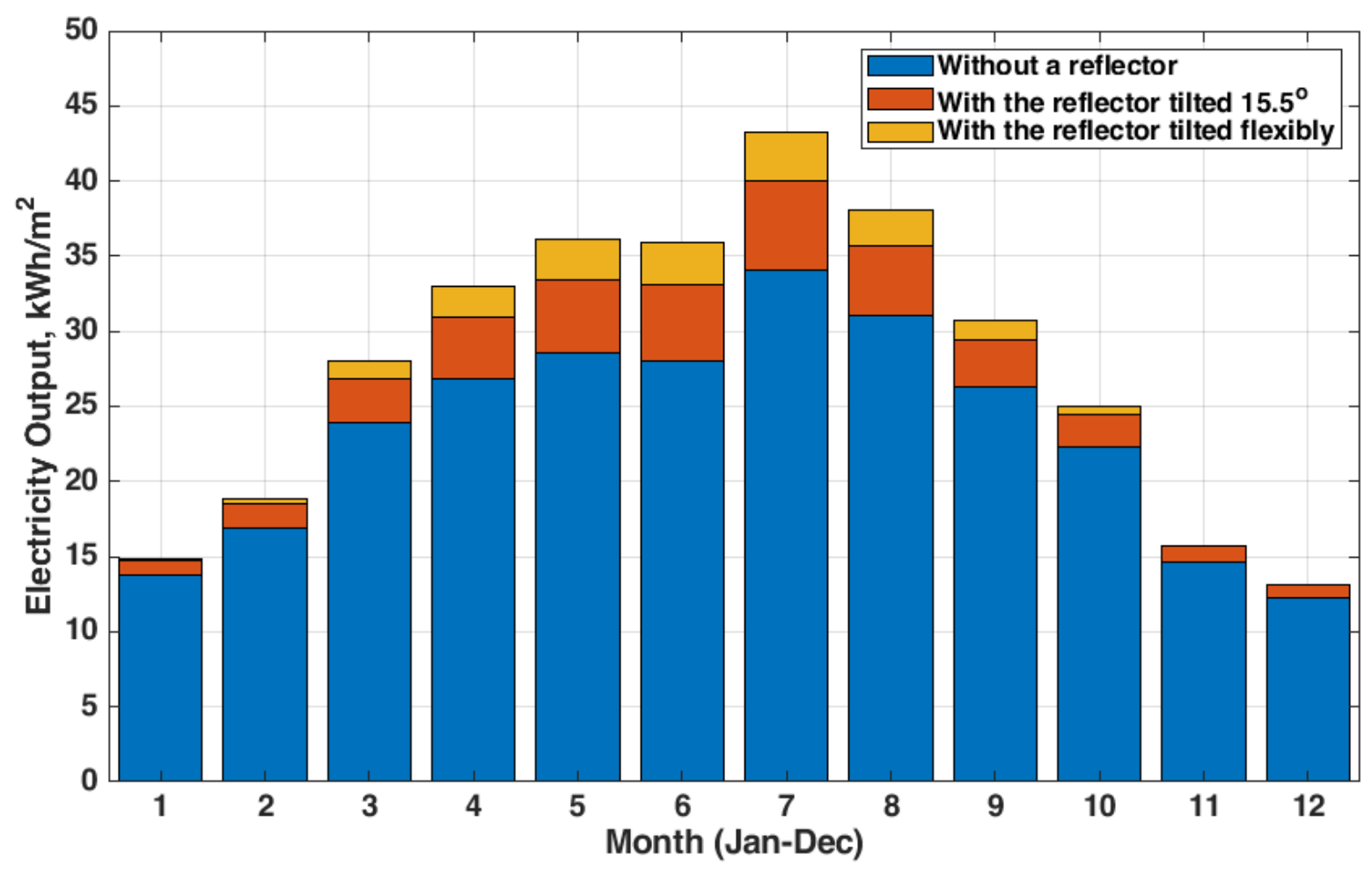

Figure 13. Annual electricity output using PV panels tilted $60^{\circ}$ without and with the reflector. 


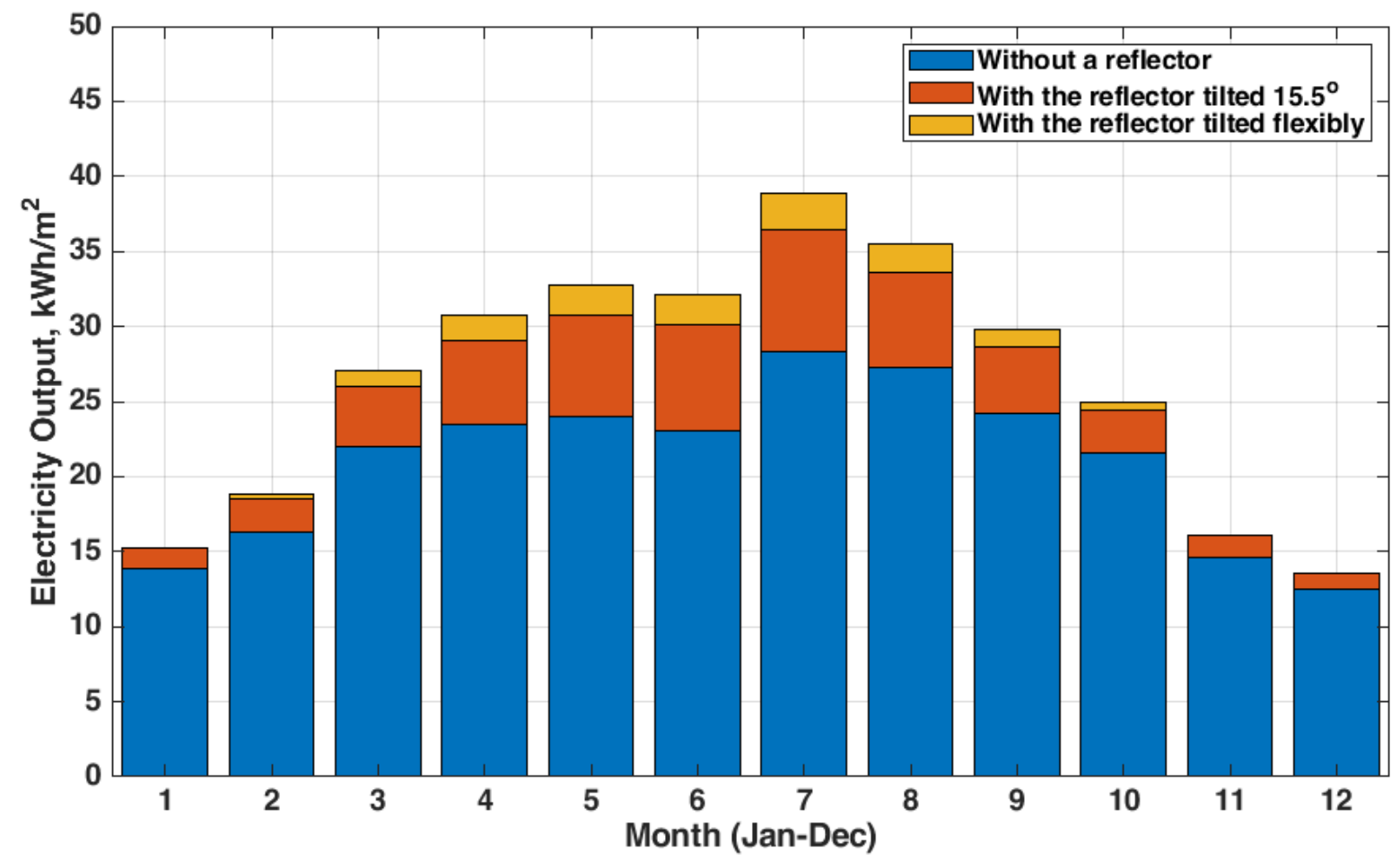

Figure 14. Annual electricity output using PV panels tilted $75^{\circ}$ without and with the reflector.

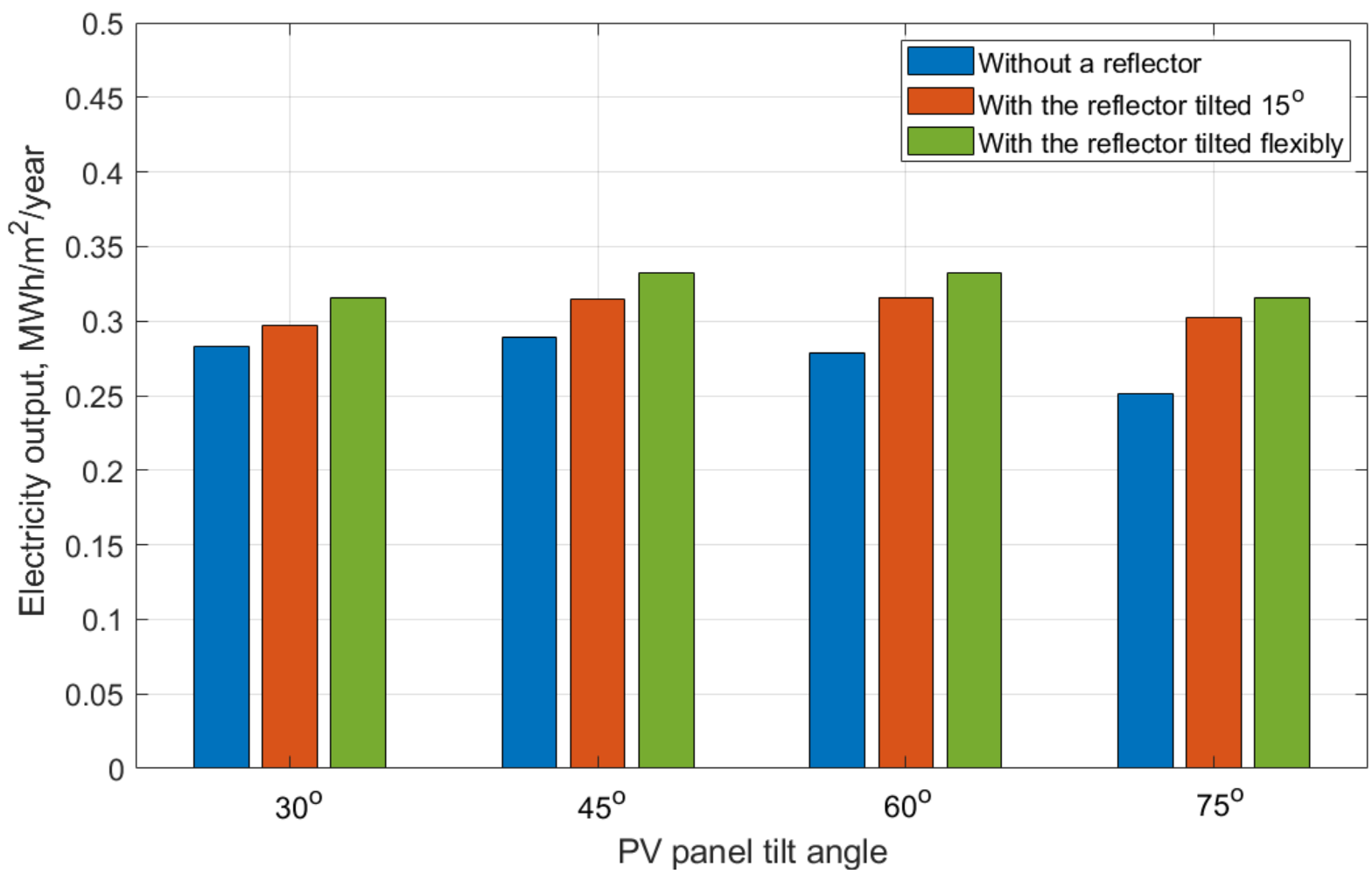

Figure 15. Annual electricity output having four different tilt angles without and with the reflector.

Conventionally, a moving solar-tracking system presents a method to obtain additional solar radiation. However, this method combines a typical PV panel with a reflector. It demonstrates the possibility of increasing solar radiation gains with a relatively low cost compared to a PV panel extended. This novel system can improve the electricity output of PV panels at a low cost. The reflector reduces the cooling load in a building because 
the material can reflect direct solar radiation to the sky and provide shade. The reflector improves the gathering of solar radiation by the PV panel tilted at high angles. Therefore, it could be effectively used for building integrated photo voltaic (BIPV) system in the future. However, the reflector can increase the surface temperature of the PV panels during the summer season since the optimal tilted PV panel achieves an additional 5-15\% solar radiation.

Additionally, some technical improvement remains to be explored via future studies. The reflection can increase the surface temperature of PV panels, and thus both ambient temperature and reflected thermal energy impact the surface temperature of PV panels and the electricity generation. Future study should consider how the reflectors, ambient temperature, and air velocity influence the thermal energy and electricity generation with experimental studies in a building. We could also consider finding other materials for the reflectors to improve reflectivity and performance. Other studies such as life cycle analysis and the environmental impact of this system would be suggested.

\section{Conclusions}

This study explores how a solar reflector impacts solar radiation collection by PV panels in a given area and how the design of a new reflector with the optimized tilt angle can minimize blocking the direct solar radiation toward PV panels. Recent studies have presented the determination of the optimal tilt angle for PV panels. This study shows the performance evaluation of solar radiation collection by combining PV panels with an aluminum reflector by local solar irradiance, Calgary, Canada. Understanding the determination of the optimal tilt angle of the PV panel in a local area is essential to obtaining solar radiation on the PV panel. As a case study, this study analyzed the performance of solar PV panels with an aluminum reflector at Calgary in Canada, employed on the existing solar radiation data, GHI and DNI in Calgary, using sensitive numerical analysis and data from the Natural Resources Canada database to assess the impact of the reflector added on PV panels in a building. The reflector fixed can improve around 5.5-9.2\% of the solar radiation gain on the PV panel with lower tilted angles and 14.1-21.1\% on the panel with higher tilted angles. Moreover, the flexibly adjusted reflector can improve around $12-15.6 \%$ of the solar radiation gain on the PV panel with lower tilted angles and $20-26.5 \%$ on the panel with higher tilted angles. The reflector tilted $15.5^{\circ}$ affects to obtain electricity output additionally by an average $4-8 \%$ with PV panel tilted $30^{\circ}$ and $45^{\circ}$ respectively and $12-19 \%$ with PV panel tilted $60^{\circ}$ and $75^{\circ}$ annually. Furthermore, the reflector tilted flexibly affects to obtain electricity output additionally by an average $9-12 \%$ with PV panel tilted $30^{\circ}$ and $45^{\circ}$ and $17-23 \%$ with PV panel tilted $60^{\circ}$ and $75^{\circ}$. Therefore, the utilization of a reflector shows the same effect to install the PV panel additionally. The reflector significantly impacts the increase of solar radiation and electricity output in higher tilted PV panels. Additionally, there are some technical limitations that remained to be explored via further studies. Additional thermal solar irradiance from the reflector and surrounding ambient temperature variations can affect the surface temperature of PV panels and electricity outputs. In future works, we should consider both impacts of extra thermal heat gains from the reflector and ambient temperature variations with experimental approaches.

Author Contributions: Conceptualization, M.K.K. and K.O.A.; methodology, M.K.K., J.L., and K.O.A.; software, M.K.K. and K.O.A.; validation, M.K.K.; formal analysis, M.K.K., J.-H.C.; investigation, M.K.K. and K.O.A.; resources, M.K.K. and K.O.A.; data curation, M.K.K. and K.O.A.; writing—original draft preparation, M.K.K. and K.O.A.; writing—review and editing, M.K.K., J.L., J.-H.C.; visualization M.K.K.; supervision, M.K.K., H.W.; project administration, M.K.K., H.W. All authors have read and agreed to the published version of the manuscript.

Funding: This research received no external funding.

Institutional Review Board Statement: Not applicable.

Informed Consent Statement: Not applicable. 
Data Availability Statement: Data sharing needs permissions.

Acknowledgments: This work was supported by Oslo Metropolitan University and the Plan of Introduction and Cultivation for Young Innovative Talents in Colleges and Universities of Shandong Province.

Conflicts of Interest: The authors declare no conflict of interest.

\section{References}

1. Lynn, P.A. Electricity from Sunlight: An Introduction to Photovoltaics; John Wiley \& Sons: New York, NY, USA, 2010.

2. Chen, C.J. Physics of Solar Energy; John Wiley \& Sons: New York, NY, USA, 2011.

3. Mackay, M.E. Solar Energy: An Introduction, 1st ed.; Oxford University Press: Oxford, UK, 2015.

4. $\quad$ Lasnier, F.; Ang, T.G. Photovoltaic Engineering Handbook; CRC Press: Boca Raton, FL, USA, 2017.

5. Kuhn, T.E.; Erban, C.; Heinrich, M.; Eisenlohr, J.; Ensslen, F.; Neuhaus, D.H. Review of Technological Design Options for Building Integrated Photovoltaics (BIPV). Energy Build. 2021, 231, 110381. [CrossRef]

6. Conceição, R.; Silva, H.G.; Fialho, L.; Lopes, F.M.; Collares-Pereira, M. PV System Design with the Effect of Soiling on the Optimum Tilt Angle. Renew. Energy 2019, 133, 787-796. [CrossRef]

7. Tırmıkçı, C.A.; Yavuz, C. Determining Optimum Tilt Angles of Solar Surfaces in Sakarya, Turkey. Theor. Appl. Clim. 2018, 133, 15-22. [CrossRef]

8. Jacobson, M.Z.; Jadhav, V. World Estimates of PV Optimal Tilt Angles and Ratios of Sunlight Incident upon Tilted and Tracked PV Panels Relative to Horizontal Panels. Sol. Energy 2018, 169, 55-66. [CrossRef]

9. Statler, N.E.; Adams, A.M.; Eckmann, T.C. Optimizing Angles of Rooftop Photovoltaics, Ratios of Solar to Vegetated Roof Systems, and Economic Benefits, in Portland, Oregon, USA. Environ. Syst. Decis. 2017, 37, 320-331. [CrossRef]

10. Yadav, A.K.; Chandel, S. Tilt Angle Optimization to Maximize Incident Solar Radiation: A Review. Renew. Sustain. Energy Rev. 2013, 23, 503-513. [CrossRef]

11. Breyer, C.; Schmid, J. Global Distribution of Optimal Tilt Angles for Fixed Tilted PV Systems. Horizon 2010, 2, 1-7.

12. Kostić, L.; Pavlović, T.; Pavlović, Z. Optimal Design of Orientation of PV/T Collector with Reflectors. Appl. Energy 2010, 87, 3023-3029. [CrossRef]

13. Lee, C.-S.; Lee, H.; Choi, M.; Yoon, J. Design Optimization and Experimental Evaluation of Photovoltaic Double Skin Facade. Energy Build. 2019, 202, 109314. [CrossRef]

14. Zomer, C.; Rüther, R. Simplified Method for Shading-loss Analysis in BIPV Systems-Part 1: Theoretical Study. Energy Build. 2017, 141, 69-82. [CrossRef]

15. Zomer, C.; Rüther, R. Simplified Method for Shading-loss Analysis in BIPV Systems. Part 2: Application in Case Studies. Energy Build. 2017, 141, 83-95. [CrossRef]

16. Kern, J.; Harris, I. On the Optimum Tilt of a Solar Collector. Sol. Energy 1975, 17, 97-102. [CrossRef]

17. Lewis, G. Optimum Tilt of a Solar Collector. Sol. Wind Technol. 1987, 4, 407-410. [CrossRef]

18. Talebizadeh, P.; Mehrabian, M.A.; Abdolzadeh, M. Determination of Optimum Slope Angles of Solar Collectors Based on New Correlations. Energy Sources Part A Recover. Util. Environ. Eff. 2011, 33, 1567-1580. [CrossRef]

19. Breyer, C.; Schmid, J. Global Distribution of Optimal Tilt Angles for Fixed Tilted PV Systems. In Proceedings of the 25th European Photovoltaic Solar Energy Conference and Exhibition/5th World Conference on Photovoltaic Energy Conversion, Valencia, Spain, 6-10 September 2010.

20. Ekpenyong, A.I.; Umoren, A.M.; Markson, I. Development of Winter Season Optimal Tilt Angle Model for Fixed Tilted Plane PV Installation in Akwa Ibom State, Nigeria. Math. Softw. Eng. 2017, 3, 67-77.

21. Nsengiyumva, W.; Chen, S.G.; Hu, L.; Chen, X. Recent Advancements and Challenges in Solar Tracking Systems (STS): A Review. Renew. Sustain. Energy Rev. 2018, 81, 250-279. [CrossRef]

22. Hoffmann, F.M.; Molz, R.F.; Kothe, J.V.; Nara, E.O.B.; Tedesco, L.P.C. Monthly Profile Analysis Based on a Two-axis Solar Tracker Proposal for Photovoltaic Panels. Renew. Energy 2018, 115, 750-759. [CrossRef]

23. Helwa, N.H.; Bahgat, A.B.G.; El Shafee, A.M.R.; El Shenawy, E.T. Maximum Collectable Solar Energy by Different Solar Tracking Systems. Energy Sources 2000, 22, 23-34.

24. Fathabadi, H. Novel High Efficient Offline Sensorless Dual-axis Solar Tracker for Using in Photovoltaic Systems and Solar Concentrators. Renew. Energy 2016, 95, 485-494. [CrossRef]

25. Rezvani, A.; Khalili, A.; Mazareie, A.; Gandomkar, M. Modeling, Control, and Simulation of Grid Connected Intelligent Hybrid Battery/Photovoltaic System Using New Hybrid Fuzzy-neural Method. ISA Trans. 2016, 63, 448-460. [CrossRef]

26. Huang, Y.-X.; Bai, L.; Ai, H.; Li, W.; Yu, C.; Liu, J.; Luo, Y.-J. Influence of Trait-anxiety on Inhibition Function: Evidence from ERPs Study. Neurosci. Lett. 2009, 456, 1-5. [CrossRef] [PubMed]

27. Deb, G.; Roy, A.B. Use of Solar Tracking System for Extracting Solar Energy. Int. J. Comput. Electr. Eng. 2012, 4, 42-46. [CrossRef]

28. Sidek, M.; Azis, N.; Hasan, W.; Ab Kadir, M.; Shafie, S.; Radzi, M. Automated Positioning Dual-axis Solar Tracking System with Precision Elevation and Azimuth Angle Control. Energy 2017, 124, 160-170. [CrossRef]

29. Rubio, F.R.; Ortega, M.; Gordillo, F.; López-Martínez, M. Application of New Control Strategy for Sun Tracking. Energy Convers. Manag. 2007, 48, 2174-2184. [CrossRef] 
30. Zogbi, R.; Laplaze, D. Design and Construction of a Sun Tracker. Sol. Energy 1984, 33, 369-372. [CrossRef]

31. Pattanasethanon, S. The Solar Tracking System by Using Digital Solar Position Sensor. Am. J. Eng. Appl. Sci. $2010,3,678-682$. [CrossRef]

32. Tomson, T. Discrete Two-positional Tracking of Solar Collectors. Renew. Energy 2008, 33, 400-405. [CrossRef]

33. Benghanem, M. Optimization of Tilt Angle for Solar Panel: Case Study for Madinah, Saudi Arabia. Appl. Energy 2011, 88, 1427-1433. [CrossRef]

34. Huang, B.; Sun, F. Feasibility Study of One Axis Three Positions Tracking Solar PV with Low Concentration Ratio Reflector. Energy Convers. Manag. 2007, 48, 1273-1280. [CrossRef]

35. Kostic, L.T.; Pavlovic, T.M.; Pavlovic, Z.T. Influence of Reflectance from Flat Aluminum Concentrators on Energy Efficiency of PV/Thermal Collector. Appl. Energy 2010, 87, 410-416. [CrossRef]

36. Pavlović, Z.T.; Kostić, L.T. Variation of Reflected Radiation from All Reflectors of a Flat Plate Solar Collector during a Year. Energy 2015, 80, 75-84. [CrossRef]

37. Crawley, G.M. Solar Energy; World Scientific Series in Current Energy Issues: Volume 2; World Scientific Publishing Co. Pte Ltd.: Singapore, 2016.

38. Rees, G. Physical Principles of Remote Sensing, 3rd ed.; Cambridge University Press: Cambridge, UK, 2013.

39. Haynes, W.M. CRC Handbook of Chemistry and Physics: A Ready-Reference Book of Chemical and Physical Data, 95th ed.; CRC Press: Boca Raton, FL, USA, 2014.

40. Poulek, V.; Matuška, T.; Libra, M.; Kachalouski, E.; Sedláček, J. Influence of Increased Temperature on Energy Production of Roof Integrated PV Panels. Energy Build. 2018, 166, 418-425. [CrossRef]

41. Dubey, S.; Sarvaiya, J.N.; Seshadri, B. Temperature Dependent Photovoltaic (PV) Efficiency and Its Effect on PV Production in the World-A Review. Energy Procedia 2013, 33, 311-321. [CrossRef]

42. Arias, H.; Cabrera, J.; Hernandez, J. Performance Evaluation of a Mono-crystalline PV Module Cooled by a Flat Plate Solar Collector in Thermosyphon Mode. In Proceedings of the 2015 IEEE 42nd Photovoltaic Specialist Conference (PVSC) IEEE, New Orleans, LA, USA, 14-19 June 2015; pp. 1-5.

43. NASA's Open Data Portal. NASA. 2019. Available online: https://data.nasa.gov/Earth-Science/Prediction-Of-WorldwideEnergy-Resources-POWER-/wn3p-qsan (accessed on 15 January 2019).

44. Natural Resources Canada 2019. Available online: https:/ / www.nrcan.gc.ca (accessed on 15 January 2019).

45. Planning and Installing Photovoltaic Systems: A Guide for Installers, Architects, and Engineers, 3rd ed.; Routledge: London, UK, 2013.

46. Skoplaki, E.; Palyvos, J. On the Temperature Dependence of Photovoltaic Module Electrical Performance: A Review of Efficiency / Power Correlations. Sol. Energy 2009, 83, 614-624. [CrossRef]

47. Luque, A.; Hegedus, S. Handbook of Photovoltaic Science and Engineering, 2nd ed.; John Wiley \& Sons: New York, NY, USA, 2011.

48. Riffonneau, Y.; Bacha, S.; Barruel, F.; Ploix, S. Optimal Power Flow Management for Grid Connected PV Systems with Batteries. IEEE Trans. Sustain. Energy 2011, 2, 309-320. [CrossRef]

49. Callister, W.D., Jr.; Rethwisch, D.G. Materials Science and Engineering, 8th ed.; John Wiley \& Sons: New York, NY, USA, 2011.

50. George, A.; Anto, R. Analytical and Experimental Analysis of Optimal Tilt Angle of Solar Photovoltaic Systems. In Proceedings of the 2012 International Conference on Green Technologies (ICGT), Trivandrum, India, 18-20 December 2012; pp. $234-239$.

51. Khorasanizadeh, H.; Mohammadi, K.; Mostafaeipour, A. Establishing a Diffuse Solar Radiation Model for Determining the Optimum Tilt Angle of Solar Surfaces in Tabass, Iran. Energy Convers. Manag. 2014, 78, 805-814. [CrossRef]

52. Vidanalage, I.; Raahemifar, K. Tilt Angle Optimization for Maximum Solar Power Generation of a Solar Power Plant with Mirrors. In Proceedings of the 2016 IEEE Electrical Power and Energy Conference (EPEC), Ottawa, Canada, 12-14 October 2016; pp. 1-5.

53. Smith, C.J.; Forster, P.; Crook, R. An All-sky Radiative Transfer Method to Predict Optimal Tilt and Azimuth Angle of a Solar Collector. Sol. Energy 2016, 123, 88-101. [CrossRef]

54. Tripathy, M.; Yadav, S.; Sadhu, P.; Panda, S. Determination of Optimum Tilt Angle and Accurate Insolation of BIPV Panel Influenced by Adverse Effect of Shadow. Renew. Energy 2017, 104, 211-223. [CrossRef]

55. Eldin, S.S.; Abd-Elhady, M.; Kandil, H. Feasibility of Solar Tracking Systems for PV Panels in Hot and Cold Regions. Renew. Energy 2016, 85, 228-233. [CrossRef]

56. Liu, F.J.; Chang, T.P. Optimizing the Tilt Angle of Solar Collector under Clear Sky by Particle Swarm Optimization Method. J. Appl. Sci. Eng. 2015, 18, 167-172.

57. Zhong, Q.; Tong, D. Spatial Layout Optimization for Solar Photovoltaic (PV) Panel Installation. Renew. Energy 2020, $150,1-11$. [CrossRef]

58. Kilickaplan, A.; Bogdanov, D.; Peker, O.; Caldera, U.; Aghahosseini, A.; Breyer, C. An Energy Transition Pathway for Turkey to Achieve 100\% Renewable Energy Powered Electricity, Desalination and Non-energetic Industrial Gas Demand Sectors by 2050. Sol. Energy 2017, 158, 218-235. [CrossRef]

59. Sadiqa, A.; Gulagi, A.; Breyer, C. Energy Transition Roadmap Towards 100\% Renewable Energy and Role of Storage Technologies for Pakistan by 2050. Energy 2018, 147, 518-533. [CrossRef]

60. National Renewable Energy Laboratory, PV Watts Calculator. 2017. Available online: https://pvwatts.nrel.gov/ (accessed on 15 January 2017).

61. Fox, M.; Bertsch, G.F. Optical Properties of Solids. Am. J. Phys. 2002, 70, 1269-1270. [CrossRef] 